\title{
Microclimate modification using eco-friendly nets and floating row covers improves tomato (Lycopersicon esculentum) yield and quality for small holder farmers in East Africa
}

\author{
Mwanarusi Saidi ${ }^{1}$, Elisha O. Gogo ${ }^{1}$, Francis M. Itulya ${ }^{1}$, Thibaud Martin ${ }^{2,3}$, Mathieu Ngouajio $^{4^{*}}$ \\ ${ }^{1}$ Department of Crops, Horticulture and Soils, Egerton University, Egerton, Kenya; \\ ${ }^{2}$ CIRAD UR Hortsys, Avenue Agropolis, Montpellier, France \\ ${ }^{3}$ Icipe, Plant Health Department, Nairobi, Kenya \\ ${ }^{4}$ Department of Horticulture, Michigan State University, East Lansing, USA; \\ *Corresponding Author: ngouajio@msu.edu
}

Received 19 May 2013; revised 21 June 2013; accepted 15 July 2013

Copyright (C) 2013 Mwanarusi Saidi et al. This is an open access article distributed under the Creative Commons Attribution License, which permits unrestricted use, distribution, and reproduction in any medium, provided the original work is properly cited.

\begin{abstract}
Tomato (Lycopersicon esculentum) is one of the important vegetables in supplying vitamins, minerals and fiber to human diets worldwide. Its successful production in the tropics is, however, constrained by environmental variations especially under open field conditions. Two trials were conducted at the Horticulture Research and Teaching Field, Egerton University, Kenya to evaluate the effects of agricultural nets (agronets) herein called eco-friendly nets (EFNs) and floating row covers (FRCs) on microclimate modification, yield, and quality of tomato. A randomized complete block design with five replications was used. Tomato plants were grown under fine mesh EFN (0.4-mm pore diameter) cover, large mesh EFN (0.9-mm pore diameter) cover or FRC. The EFN and FRC were maintained either permanently closed or opened thrice a week from $9 \mathrm{am}$ to $3 \mathrm{pm}$. Two open control treatments were used: unsprayed (untreated control) or sprayed with chemicals (treated control). The use of EFN or FRC modified the microclimate with higher temperatures, lower diurnal temperature ranges, and higher volumetric water content recorded compared with the controls. On the other hand, light quantity and photosynthetic active radiation were reduced by the use of EFN and FRC compared with the controls. The use of FRC and EFN resulted in more fruit and higher percent in marketable yield com-
\end{abstract}

pared with open field production. Fruit quality at harvest was also significantly improved by the use of EFN and FRC. Fruits with higher total soluble solids (TSS), lower titratable acidity (TA), and higher sugar acid ratio were obtained in EFN and FRC treatments compared with the controls. Fruits harvested from EFN and FRC were also firmer compared with control fruits. These findings demonstrate the potential of EFN and FRC in modifying microclimate conditions and improving yields and quality of tomato under tropical field conditions.

Keywords: Lycopersicon esculentum; Solanum lycopersicum; Microclimate Modification; Protected Cropping; Tomato Yields; Tomato Quality

\section{INTRODUCTION}

Tomato is a popular and versatile food crop grown and consumed all over the world [1]. The popularity of tomato among consumers has made it an important source of vitamins, minerals, and fiber in the diets of many people. Besides, tomato contains good amounts of lycopene, an antioxidant which purportedly fights free radicals that can interfere with normal cell growth and activity; thus reducing cancer, heart diseases and premature aging [2]. Successful production of the crop in the tropics, however, suffers from environmental variations, especially in the open fields. This affects growth of the crop leading to poor yield and quality [3-5].

Temperature and soil moisture have been documented 
among the main environmental factors that to a large extent affect tomato growth [6]. Temperatures below $10^{\circ} \mathrm{C}$ or above $30^{\circ} \mathrm{C}$ affect growth and development of tomato leading to low yield and poor fruit quality. Tomato also requires adequate soil moisture for its growth and development. Too much or limited soil moisture similarly leads to low yield and poor fruit quality. Although, tomato requires light for the process of photosynthesis, the crop may still produce better yields under reduced light conditions $[7,8]$.

The use of EFNs and FRCs in protected cultivation was tested in Africa [9,10] and Europe [11], respectively and proved to be effective in microclimate modification. EFNs were also used in Kenya to improve tomato and cabbage (Brassica oleracea var. capitata) transplant production $[12,13]$. As a result of microclimate improvement, EFNs and FRCs have been reported to significantly alter air temperature and soil moisture which influence plant growth through changes in leaf characteristics, biomass accumulation, and relative growth rate leading to better yield and crop quality [14]. The present study aimed at investigating the effects of EFNs and FRCs on microclimate improvement, yield, and quality of tomato under tropical field conditions.

\section{MATERIALS AND METHODS}

\subsection{Experimental Site}

The study was conducted at the Horticulture Research and Teaching Field, Egerton University, Njoro, Kenya in two seasons (May to Oct. 2011 and Oct. 2011 to Mar. 2012). The field lies at latitude of $0^{\circ} 23^{\prime} \mathrm{S}$ and longitude $35^{\circ} 35^{\prime} \mathrm{E}$ in the Lower Highland III Agro Ecological Zone (LH3) at an altitude of $2238 \mathrm{~m}$ above sea level. The average maximum and minimum temperatures range from 19 to $22^{\circ} \mathrm{C}$ and 5 to $8^{\circ} \mathrm{C}$, respectively, with a mean total annual rainfall of 1200 to $1400 \mathrm{~mm}$. Soils are predominantly andosols with a pH of 6.0 to 6.5 [15].

\subsection{Planting Material, Experimental Design, and Treatments}

"Rio Grande" tomato transplants were used as the planting material in the study. Seedlings used were started under an eco-friendly net (0.4-mm pore diameter) covered nursery to ensure that they were of superior quality and virus free. The experiment was laid in a randomized complete block design (RCBD) with five replications and 8 treatments as follows: 1) open unsprayed (untreated control), 2) open sprayed with synthetic insecticides (treated control), 3) FRC maintained permanently covered, 4) fine mesh (0.4-mm pore diameter) $\mathrm{EFN}$ maintained permanently covered, v) large mesh $(0.9-\mathrm{mm}$ pore diameter) EFN maintained permanently covered, 5) FRC opened three times a week from 9:00 am to 3:00 pm,
6) fine mesh (0.4-mm pore diameter) EFN opened three times a week from 9:00 am to 3:00 pm, and 7) large mesh (0.9-mm pore diameter) EFN opened three times a week from 9:00 am to 3:00 pm. Row covers used were manufactured by Agribon, Mooreville, NC while the EFN were manufacture by A to Z Textile Mills, Arusha, Tanzania. Each block measured $71 \times 1 \mathrm{~m}$ separated by a 1-m buffer. Within each block, individual experimental units measured $1 \times 8 \mathrm{~m}$ separated by a $0.5-\mathrm{m}$ buffer. In every plot, three posts $1.2-\mathrm{m}$ long were placed $4-\mathrm{m}$ apart along the $8-\mathrm{m}$ bed to serve as the support system for the cover and the crop. These were grounded to $20-\mathrm{cm}$ depth to ensure that they were firm enough to provide the needed support. Binding wire was then pinned at $30-\mathrm{cm}$ interval from the ground to the top of the posts to complete the crop support system. Additionally, for the covered treatments, ordinary mild steel (R6) $1 \mathrm{~m}$ long pieces were mounted on top of each post, fastened using U-nail and bent to provide a tunnel shape top for dressing the covers. Covers used on each experimental unit measured 3-m wide and 11-m long.

\subsection{Land Preparation and Maintenance Practices}

The field was ploughed to $\sim 20-\mathrm{cm}$ depth and later harrowed to a fine tilth using disc plough and harrow, respectively. Transplanting holes were manually dug using hand hoes and diammonium phosphate $(18 \% \mathrm{~N}, 46 \%$ $\mathrm{P}_{2} \mathrm{O}_{5}$ ) applied at $10 \mathrm{~g}$ per hole and thoroughly mixed with the soil prior to transplanting. Four weeks old tomato seedlings were transplanted in one row 8-m long at 50$\mathrm{cm}$ spacing within the row [1] giving 16 tomato plants per experimental unit. Before covering the plots with EFN or FRC, all plots received a blanket spray of insecticide (alpha-cypermethrin 10\% EC) at the rate of 25 $\mathrm{ml} / 201$ of water provided by Meya Agricultural Traders, Nakuru, Kenya to take care of pests during the transplanting process. Thereafter, standard good agricultural practices including fertilizer application, watering, weeding and training were done uniformly on all experimental units on need basis.

\subsection{Data Collection}

Data for all variables measured were collected from the middle 14 plants in all the experimental units.

Microclimate: WatchDog Plant Growth Station data loggers (2475; Spectrum Technologies, Plainfield, IL) were used to collect climatic data. Each Data logger was screwed $0.5-\mathrm{m}$ high on a wooden post at the center of each treatment. Data were recorded and averaged weekly. On weekly basis, the data were downloaded into the computer and hard copies printed to ensure safety. Data collected included; air temperature $\left({ }^{\circ} \mathrm{C}\right)$, diurnal tempera- 
ture range $\left({ }^{\circ} \mathrm{C}\right)$, volumetric water content $(\%)$ using an external sensor (WaterScoutTM SM 100), photosynthetically active radiation $\left(\mathrm{mmol} \cdot \mathrm{m}^{-2} \cdot \mathrm{s}^{-1}\right)$, and daily light integral $\left(\mathrm{mol} \cdot \mathrm{d}^{-1}\right)$.

Yield: Fruit harvesting was piece meal on weekly basis over a period of four weeks. Physiologically mature fruit at pink stage were harvested from the 14 middle plants in each treatment. At each harvest, total and marketable fruit number and weight from each experimental unit was taken and recorded. Percentage increase in marketable yield was also computed using the yield of the untreated control as the base.

Quality: Fruit quality variables measured in this study were firmness, total soluble solids (TSS), titratable acidity (TA) and sugar:acid ratio. Tomato fruit at red ripe stage was used. Fruit firmness $(\mathrm{KgF})$ was determined using a hand held penetrometer (FT327; Shangai Precision and Scientific Instrument Co., Shangai, China). Total soluble solids were determined using a hand held refractometer (RHB; Shangai Precision and Scientific Instrument Co., Shangai, China) as per the procedure described by Tigchelaar [16]. Titratable acidity (TA) was determined for the same fruit used to determine total soluble solids using the coloured indicator method as described by Turhan and Seniz [17]. Sugar acid ratio was computed using the formula; Sugar:acid ratio $=\%$ Brix value/Percentage acid [18].

\subsection{Data Analysis}

The Proc univariate procedure of SAS (version 9.1; SAS Institute, Cary, NC) was used to check for normality of the data before analysis. Data were then subjected to analysis of variance (ANOVA) using the GLM at $P \leq$ 0.05. Data for the two seasons were pooled together and analyzed using the statistical model: $\boldsymbol{Y}_{i j}=\boldsymbol{\mu}+\boldsymbol{\beta}_{\boldsymbol{i}}+\boldsymbol{\alpha}_{j}+\boldsymbol{\varepsilon}_{i j}$ where; $\boldsymbol{Y}_{i j}$ is the tomato response, $\mu$ is the overall mean, $\boldsymbol{\beta}_{\boldsymbol{i}}$ is the $\boldsymbol{i}^{\text {th }}$ blocking effect, $\boldsymbol{\alpha}_{\boldsymbol{j}}$ is the effect due to the $\boldsymbol{j}^{\boldsymbol{t h}}$ treatment and $\varepsilon_{i j}$ is the random error term. Means for significant treatments, at the F test, were separated using Tukey's honestly significant difference (THSD) test at $P$ $\leq 0.05$

\section{RESULTS}

\subsection{Temperature}

Covering plants with FRC or EFN influenced temperature within the vicinity of tomato plants. Throughout the study, the highest temperatures were recorded under FRC maintained permanently covered (Figure 1). Mean temperature for this treatment for the two seasons was $23.5^{\circ} \mathrm{C}$. Among the other treatments, mean temperatures were $23.0,22.7,21.7,21.3$, and $20.9^{\circ} \mathrm{C}$, under FRC opened thrice a week, 0.4-mm EFN covered permanently, 0.4-mm EFN opened thrice a week, 0.9-mm EFN cov-

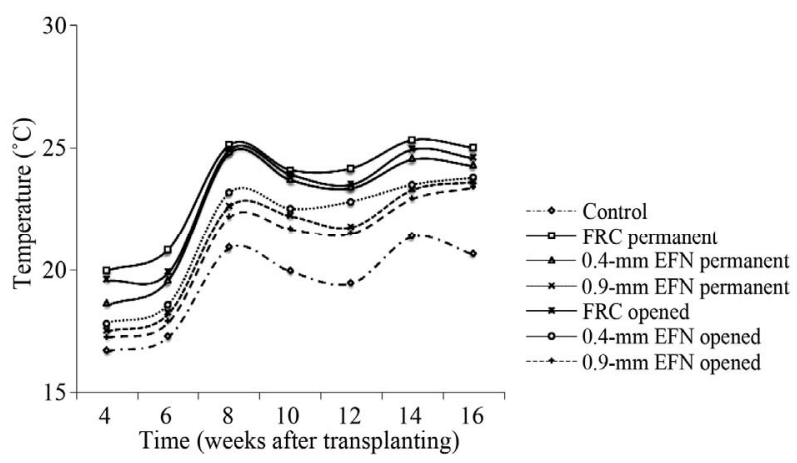

Figure 1. Effects of floating row covers and eco-friendly nets on weekly temperature during tomato production. Values shown are averaged across the two seasons (Season 1, May to Oct. 2011 and Season 2, Oct. 2011 to Mar. 2012). Control was where the crop was uncovered; permanent is where the FRC or EFN were covered throughout except during crop maintenance periods, and opened is where the FRC or EFN were opened thrice a week from 9.00 am to $3.00 \mathrm{pm}$.

ered permanently, and $0.9-\mathrm{mm}$ EFN opened thrice a week, respectively compared with $19.4^{\circ} \mathrm{C}$ for the control.

\subsection{Diurnal Temperature Range}

The use of FRC and EFN covers reduced the diurnal temperature range throughout the study period (Figure 2). Averaged over the two growing seasons, FRC and 0.4-mm EFN maintained permanently covered gave the lowest diurnal temperature ranges of $3.3^{\circ} \mathrm{C}$ and $3.4^{\circ} \mathrm{C}$, respectively compared with the control $\left(5.8^{\circ} \mathrm{C}\right)$. Among the other treatments, diurnal temperature range was lower under FRC opened thrice a week $\left(3.7^{\circ} \mathrm{C}\right)$, followed by $0.4-\mathrm{mm}$ net opened thrice a week $\left(4.1^{\circ} \mathrm{C}\right)$, then 0.9 $\mathrm{mm}$ net covered permanently $\left(4.2^{\circ} \mathrm{C}\right)$ and highest under $0.9-\mathrm{mm}$ EFN cover opened thrice a week $\left(4.5^{\circ} \mathrm{C}\right)$.

\subsection{Soil Moisture}

The use of FRC and EFN maintained higher soil moisture content (measured as volumetric water content) throughout the study period (Figure 3). Averaged over the two study seasons, FRC and 0.4-mm EFN used permanently maintained the highest soil moisture with means of $33.7 \%$ and $33.3 \%$, respectively. The lowest mean soil moisture content $(22.5 \%)$ was recorded under the control treatment. Among the other treatments, mean soil moisture content was $32.5 \%, 31.2 \%, 30.8 \%$, and $30.0 \%$ for FRC opened thrice a week, 0.9-mm net covered permanently, 0.4-mm net opened thrice a week, and 0.9-mm net opened thrice a week, respectively.

\subsection{Photosynthetically Active Radiation}

Floating row covers (FRC) and EFN covering affected photosynthetically active radiation (PAR). Generally PAR reaching the crop was reduced by the use of FRC 


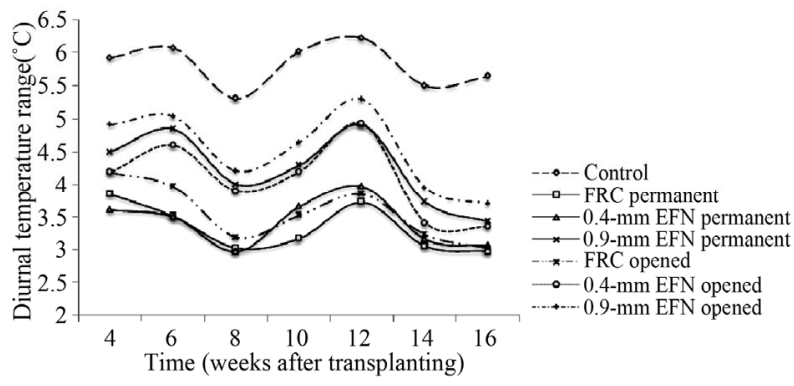

Figure 2. Effects of floating row covers and eco-friendly nets on diurnal temperature range during tomato production. Values shown are averaged across the two seasons (Season 1, May to Oct. 2011 and Season 2, Oct. 2011 to Mar. 2012). Control treatment was left uncovered; permanent is where the FRC or EFN were covered throughout except during crop maintenance periods and opened is where the FRC or EFN were opened thrice a week from 9.00 am to $5.00 \mathrm{pm}$.

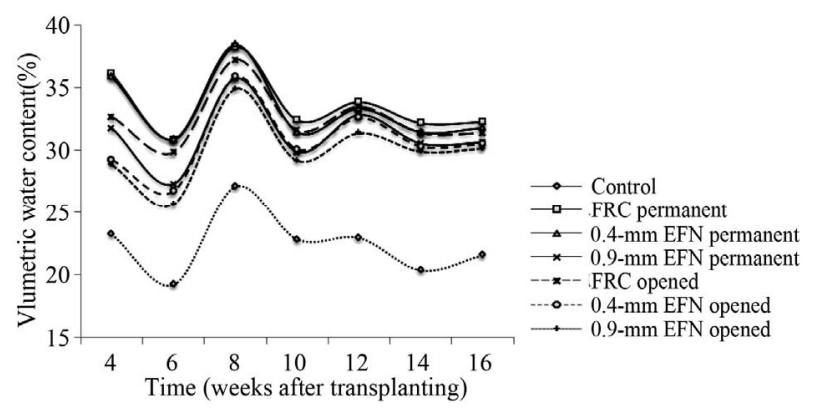

Figure 3. Effects of floating row covers and eco-friendly nets on soil moisture content (volumetric water content) during tomato production. Values shown are averaged across the two seasons (Season 1, May to Oct. 2011 and Season 2, Oct. 2011 to Mar. 2012). Control treatment was left uncovered; permanent is where the FRC or EFN were covered throughout except during crop maintenance periods and opened is where the FRC or EFN were opened thrice a week from 9.00 am to 5.00 pm.

and EFN (Figure 4). Tomato plants under the control treatment registered higher PAR levels in all sampling dates. The mean PAR received by control plants was $615.3 \mathrm{mmol} \cdot \mathrm{m}^{-2} \cdot \mathrm{s}^{-1}$ compared to $593.3,592.6,591.7$, $590.8,590.7$, and $590.6 \mathrm{mmol} \cdot \mathrm{m}^{-2} \cdot \mathrm{s}^{-1}$ recorded under 0.9-mm EFN opened thrice a week, 0.4-mm EFN opened thrice a week, 0.9-mm EFN covered permanently, FRC used permanently, FRC opened thrice a week, and 0.4$\mathrm{mm}$ EFN covered permanently, respectively.

\subsection{Light Quantity (Daily Light Integral)}

Using FRC and EFN in tomato growing reduced the light quantity that reached the crop (Figure 5). Control plants received more light compared with plants under FRC or EFN in all data collection days. Averaged over the two seasons, control plants received $43.2 \mathrm{~mol} \cdot \mathrm{d}^{-1}$ compared with $35.7,35.4,35.1,34.6,34.5$, and 34.2 $\mathrm{mol} \cdot \mathrm{d}^{-1}$ under 0.9-mm EFN opened thrice a week, 0.4-

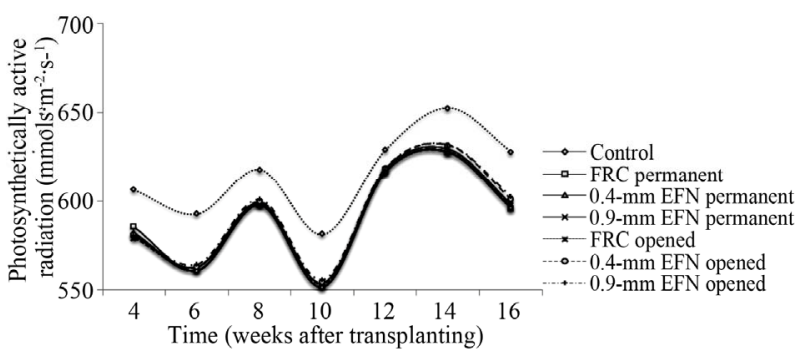

Figure 4. Effects of floating row covers and ecofriendly nets on photosynthetically active radiation during tomato production. Values shown are averaged across the two seasons (Season 1, May to Oct. 2011 and Season 2, Oct. 2011 to Mar. 2012). Control treatment was left uncovered; permanent is where the FRC or EFN were covered throughout except during crop maintenance periods and opened is where the FRC or EFN were opened thrice a week from 9.00 am to $5.00 \mathrm{pm}$.

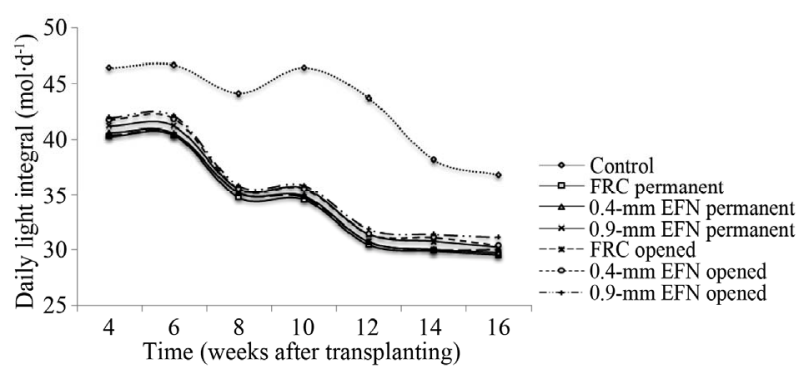

Figure 5. Effects of floating row covers and eco-friendly nets on light quantity during tomato production. Values shown are averaged across the two season (Season 1, May to Oct. 2011 and Season 2, Oct. 2011 to Mar. 2012). Control treatment was left uncovered; permanent is where the FRC or EFN were covered throughout except during crop maintenance periods and opened is where the FRC or EFN were opened thrice a week from 9.00 am to $5.00 \mathrm{pm}$.

mm EFN opened thrice a week, 0.9-mm EFN covered permanently, 0.4-mm EFN covered permanently, FRC opened thrice a week, and FRC used permanently, respectively.

Total Fruit Yield: Growing tomato under EFN or FRC significantly increased tomato yield (Table 1). The use of FRC maintained permanently covered resulted in the highest total fruit number with the lowest fruit number obtained in the treated control and the 0.9-mm EFN maintained permanently covered. Among the other treatments, more fruits were harvested from plants under the FRC opened thrice a week followed by the untreated control, 0.4-mm EFN maintained permanently, 0.4-mm EFN opened thrice a week, and 0.9-mm EFN opened thrice a week treatment in descending order. In terms of total fruit fresh weight, FRC maintained permanently covered had the highest yield while the untreated control gave the lowest yield (Table 2). Superiority in total fresh fruit weight among the other treatments followed the order; treated control, 0.9-mm EFN opened thrice a week, 0.9-mm EFN maintained permanently, 0.4-mm EFN 
Table 1. Effects of floating row covers (FRC) and eco-friendly nets $(\mathrm{EFN})$ on tomato yield $\left(\right.$ no. $\left./ \mathrm{m}^{2}\right)$ during production. The values shown are averaged across the two seasons, May to Oct. 2011 and Oct. 2011 to Mar. 2012.

\begin{tabular}{cccc}
\hline Treatment & $\begin{array}{c}\text { Total fruit } \\
\left(\mathrm{no} . / \mathrm{m}^{2}\right)\end{array}$ & $\begin{array}{c}\text { Marketable } \\
\text { fruit } \\
\left(\text { no. } / \mathrm{m}^{2}\right)\end{array}$ & $\begin{array}{c}\text { Increase in } \\
\text { marketable fruit } \\
\text { number }(\%)^{* * *}\end{array}$ \\
\hline Untreated control & $41.2 \mathrm{bc}^{* *}$ & $31.8 \mathrm{e}$ & 0 \\
Treated control & $38.8 \mathrm{e}$ & $35.4 \mathrm{~d}$ & 11.3 \\
FRC permanent & $43.0 \mathrm{a}$ & $42.0 \mathrm{a}$ & 32.1 \\
0.4-mm EFN permanent & $40.6 \mathrm{c}$ & $39.0 \mathrm{~b}$ & 22.6 \\
0.9-mm EFN permanent & $38.8 \mathrm{e}$ & $35.8 \mathrm{~cd}$ & 12.6 \\
FRC opened & $42.6 \mathrm{ab}$ & $40.0 \mathrm{~b}$ & 25.8 \\
0.4-mm EFN opened & $40.4 \mathrm{~cd}$ & $36.8 \mathrm{c}$ & 15.7 \\
0.9-mm EFN opened & $39.0 \mathrm{de}$ & $34.8 \mathrm{~d}$ & 9.4 \\
\hline
\end{tabular}

*Untreated control had no pesticide applied, treated control was sprayed with pesticides, permanent is where the FRC or EFN were covered throughout except during crop maintenance periods and opened is where the FRC or EFN were opened thrice a week from 9.00 am to $3.00 \mathrm{pm}$. ${ }^{* *}$ Means followed by the same letter within a column and a parameter are not significantly different according to Tukey's honestly significant difference (THSD) at $P \leq$ $0.05 .{ }^{* * *}$ Percent increase in marketable yield $=\mathrm{x}$-untreated control/untreated control $\times 100$, where $\mathrm{x}$ is marketable yield for the given treatment.

Table 2. Effects of floating row covers (FRC) and eco-friendly nets $(\mathrm{EFN})$ on tomato yield $\left(\mathrm{Kg} / \mathrm{m}^{2}\right)$ during production. The values shown are averaged across the two seasons, May to Oct. 2011 and Oct. 2011 to Mar. 2012.

\begin{tabular}{cccc}
\hline Treatment & $\begin{array}{c}\text { Total fruit } \\
\left(\mathrm{Kg} / \mathrm{m}^{2}\right)\end{array}$ & $\begin{array}{c}\text { Marketable } \\
\text { fruit } \\
\left(\mathrm{Kg} / \mathrm{m}^{2}\right)\end{array}$ & $\begin{array}{c}\text { Increase in } \\
\text { marketable fruit } \\
\text { weight }(\%)^{* * *}\end{array}$ \\
\hline Untreated control & $3.8 \mathrm{~g}^{* *}$ & $3.0 \mathrm{f}$ & 0.0 \\
Treated control & $4.4 \mathrm{f}$ & $4.0 \mathrm{e}$ & 33.3 \\
FRC permanent & $7.6 \mathrm{a}$ & $7.4 \mathrm{a}$ & 146.7 \\
0.4-mm EFN permanent & $6.2 \mathrm{c}$ & $6.0 \mathrm{c}$ & 100.0 \\
0.9-mm EFN permanent & $5.2 \mathrm{ed}$ & $4.8 \mathrm{~d}$ & 60.0 \\
FRC opened & $6.8 \mathrm{~b}$ & $6.4 \mathrm{~b}$ & 113.3 \\
0.4-mm EFN opened & $6.0 \mathrm{~d}$ & $4.8 \mathrm{~d}$ & 60.0 \\
0.9-mm EFN opened & $4.8 \mathrm{ef}$ & $4.2 \mathrm{e}$ & 40.0 \\
\hline
\end{tabular}

*Untreated control had no pesticide applied, treated control was sprayed with pesticides, permanent is where the FRC or EFN were covered throughout except during crop maintenance periods and opened is where the FRC or EFN were opened thrice a week from 9.00 am to $3.00 \mathrm{pm} .{ }^{* *}$ Means followed by the same letter within a column and a parameter are not significantly different according to Tukey's honestly significant difference (THSD) at $P \leq$ $0.05{ }^{* * *}$ Percent increase in marketable yield $=\mathrm{x}$-untreated control/untreated control $\times 100$, where $\mathrm{x}$ is marketable yield from the treatment.

opened thrice a week, 0.4-mm EFN maintained permanently and FRC opened thrice a week.

Marketable Yield: The number of marketable fruit was also influenced by the use of EFN and FRC covers. Growing tomato under FRC maintained permanently covered yielded the highest number of marketable fruit
(Table 1). The lowest number of marketable fruit was, on the other hand, obtained from the untreated control. Among the other treatments, the FRC opened thrice a week and the 0.4-mm EFN maintained permanently covered yielded more marketable fruit numbers followed by the 0.4-mm EFN opened thrice a week, then 0.9-mm EFN maintained permanently covered, with lower numbers of marketable fruit recorded for the treated control and $0.9-\mathrm{mm}$ EFN opened thrice a week treatments. The trend was similar for marketable fresh fruit weight (Table 2). The highest marketable fruit fresh weight was obtained from the FRC maintained permanently covered. Among the other treatments, marketable fresh fruit weight was higher under FRC opened thrice a week followed by $0.4-\mathrm{mm}$ EFN maintained permanently, 0.4-mm EFN opened thrice a week, 0.9-mm EFN covered permanently, 0.9-mm EFN opened thrice a week, and the treated control in a decreasing order. A similar trend was also observed for marketable fresh fruit weight.

Percent Marketable Fruit Gain: Using the marketable fruit yield for the untreated control as the denominator in the equation, the use of EFN and FRC influenced the percent marketable yield gain. FRC maintained permanently covered registered the highest percent increase in marketable fruit number (Table 1). Among the other treatments, increase in marketable yields followed the descending order of FRC opened thrice a week, 0.4$\mathrm{mm}$ EFN used permanently, 0.4-mm EFN opened thrice a week, 0.9-mm EFN used permanently, treated control and $0.9-\mathrm{mm}$ EFN opened thrice a week. A similar trend was observed with the percent increase in marketable fresh fruit weight (Table 2).

\subsection{Quality}

Fruit Firmness: The use of EFN and FRC in tomato growing significantly influenced tomato fruit quality (Table 3). Growing tomato under FRC permanently covered yielded firmer fruit compared with all the other treatments. The least firm fruit were obtained in the control treatments. Among the other treatments, fruit were more firm from the 0.4-mm EFN covered permanently and FRC opened thrice a week followed by 0.9-mm EFN covered permanently, 0.4-mm EFN opened thrice a week, and lowest in the 0.9-mm EFN opened thrice a week although the difference was not statistically significant $(P \leq 0.05)$.

Total Soluble Solids: Total soluble solids (TSS) of tomato fruit was significantly influenced by the use of EFN and FRC (Table 3). Fruit grown under FRC maintained permanently covered had the highest TSS while those produced in the open had the lowest TSS. Among fruit grown under the other treatments, TSS was higher in fruit grown under FRC opened thrice a week and 0.4mm EFN maintained permanently covered treatments 
Table 3. Effects of floating row covers (FRC) and eco-friendly nets (EFN) on tomato fruit quality at harvest. The values shown are averaged across the two seasons, May to Oct. 2011 and Oct. 2011 to Mar. 2012.

\begin{tabular}{ccccc}
\hline Treatment $^{*}$ & $\begin{array}{c}\text { Firmness } \\
(\mathrm{KgF})\end{array}$ & $\begin{array}{c}\text { TSS } \\
(\%)\end{array}$ & $\begin{array}{c}\text { TA } \\
(\%)\end{array}$ & $\begin{array}{c}\text { Sugar acid } \\
\text { ratio }\end{array}$ \\
\hline Untreated control & $3.2 \mathrm{~d}^{* *}$ & $2.9 \mathrm{~d}$ & $4.1 \mathrm{a}$ & $0.7 \mathrm{~d}$ \\
Treated control & $3.3 \mathrm{~d}$ & $3.1 \mathrm{~d}$ & $4.0 \mathrm{a}$ & $0.8 \mathrm{~d}$ \\
FRC permanent & $5.9 \mathrm{a}$ & $6.0 \mathrm{a}$ & $3.3 \mathrm{~b}$ & $1.8 \mathrm{a}$ \\
0.4-mm EFN permanent & $5.5 \mathrm{~b}$ & $5.8 \mathrm{~b}$ & $3.4 \mathrm{~b}$ & $1.7 \mathrm{~b}$ \\
0.9-mm EFN permanent & $5.2 \mathrm{c}$ & $5.3 \mathrm{c}$ & $3.6 \mathrm{~b}$ & $1.5 \mathrm{c}$ \\
FRC opened & $5.5 \mathrm{~b}$ & $5.7 \mathrm{~b}$ & $3.5 \mathrm{~b}$ & $1.7 \mathrm{~b}$ \\
0.4-mm EFN opened & $5.2 \mathrm{c}$ & $5.3 \mathrm{c}$ & $3.5 \mathrm{~b}$ & $1.5 \mathrm{c}$ \\
0.9-mm EFN opened & $5.1 \mathrm{c}$ & $5.2 \mathrm{c}$ & $3.6 \mathrm{~b}$ & $1.5 \mathrm{c}$ \\
\hline
\end{tabular}

*Untreated control had no pesticide applied, treated control was sprayed with pesticides, permanent is where the FRC or EFN were covered throughout except during crop maintenance periods and opened is where the FRC or EFN were opened thrice a week from 9.00 am to $3.00 \mathrm{pm} .{ }^{* *}$ Means followed by the same letter within a column and a parameter are not significantly different according to Tukey's honestly significant difference (THSD) at $P \leq$ 0.05 .

followed by 0.4-mm EFN opened thrice a week, then 0.9 -mm EFN covered permanently, and least under 0.9$\mathrm{mm}$ net opened thrice a week.

Titratable Acidity: The use of EFN and FRC significantly influenced tomato fruit TA (Table 3). The control treatments yielded fruit with the highest TA while the fruit harvested from FRC maintained permanently covered had the lowest TA. The titratable acidity of fruit grown under the other treatments was not statistically different $(P \leq 0.05)$.

Sugar Acid Ratio: Sugar acid ratio (TSS:TA) was significantly influenced by the use of FRC and EFN covers (Table 3). Fruit harvested from the control treatments had the lowest TSS:TA while fruit grown under FRC maintained permanently covered had the highest TSS:TA. Among other treatments, fruit from the 0.4-mm EFN maintained permanently covered and FRC opened thrice a week had higher TSS: TA followed by $0.4-\mathrm{mm}$ EFN opened thrice a week, then 0.9-mm EFN maintained permanently covered and lowest in 0.9 -mm EFN opened thrice a week treatment although the difference in sugar acid ratio among these treatments were not significant $(P$ $\leq 0.05)$.

\section{Discussion}

Using FRC or EFN in the current study effectively modified the microclimate around the growing tomato plants. Mean daily temperature increased with the use of FRC and EFN covers compared with the control. In addition to increasing mean daily temperature, FRC and EFN reduced the diurnal temperature range of the imme- diate crop environment. Mitigating diurnal temperature fluctuations may be beneficial for the crop. Under the covered plots, air temperature increase also tended to increase with a decrease in cover pore diameter. As expected, a reverse trend was observed with diurnal temperature range, which tended to decrease with decrease in cover pore diameter. Thus, using covers with smaller pore diameter resulted in a higher temperature and lower diurnal temperature range and vice versa. Generally, air temperature also remained consistently higher in treatments with covers maintained permanently covered compared with when the covers were opened thrice a week due to a reduction of the cover effect during the periods when the covers are open. A reverse trend was observed with diurnal temperature range, which tended to be lower in treatments with covers maintained permanently covered compared with when the covers were opened thrice a week. The use of netting and any other type of covering has been shown to restrict air movement around the growing crop resulting in higher temperature and lower diurnal temperature range $[19,20]$. Opening of nets during the growing period of plant has been shown to enhance air movement within the vicinity of the crop, leading to lower air temperatures under opened nets [21]. In a study with mesh of different sizes, Antignus et al. [22] showed that smaller mesh size nets resulted in higher air temperatures than large mesh size nets. In the current study, the higher temperatures and lower diurnal temperature range recorded for covered tomato plots compared with uncovered plots; finer mesh covers compared with larger mesh covers as well as under permanent cover compared with covers opened thrice a week could therefore be attributed to the differences in the levels of restriction in air movement around the growing tomato crop amongst the different treatments leading to a differential effect in temperature dynamics.

Soil moisture content was also higher in all covered compared with uncovered plots. Permanent use of FRC and EFN also tended to maintain higher soil moisture levels than when covers were opened thrice a week. Generally, soil moisture content was also higher under smaller pore diameter covers than under larger pore diameter covers during the study. Covering crops reduce instantaneous solar radiation through shading [23] resulting to lower evaporation from the ground, thus maintaining higher soil moisture contents [24]. This argument lends support to the higher moisture levels observed under covered plots in the current study. Majumdar [19] similarly reported higher soil moisture under net covered plots compared with uncovered plots.

Contrary to temperature and moisture levels, PAR and light quantities that reached the tomato crop were lowered by the use of EFN and FRC. A higher reduction in PAR and light quantity was also noted in treatments 
where EFN and FRC were maintained permanently covered and with decreasing cover pore diameter. Covers block light as well as reduce the light quality [22]. The reduction in PAR and light quantity under FRC and EFN observed in the current study could, therefore, be attributed to the light blocking properties of the materials used with more light being blocked when covers of smaller pore diameter were used or when the covers were maintained permanently. Although the use of EFN and FRC lowered PAR reaching the crop, the quantity of light received by the crop still remained within acceptable range and did not have major impact on the plants.

Following the microclimate modification registered under FRC and EFN treatments, improved tomato yield was also recorded in most of the covered plots. Yield also tended to increase with a decrease in cover pore diameter. Permanently covered tomato also yielded more marketable fruit, higher fruit weight, and higher percent increase in marketable yield compared with when covers were opened thrice a week. Covers have been reported to modify internal temperature, soil moisture and diurnal temperature range inside protected culture [25] which tends to favor physiological processes of plants leading to better growth and development, and subsequently higher yields [6]. In the current study, higher air temperature and soil moisture and lower diurnal temperature range was noted under covered compared with control treatments which could have favored better physiological plant development under our climatic conditions. Better physiological development translates to higher photosynthetic activities [26]. When photosynthesis is enhanced, more food is manufactured and translocated to sinks which could probably have favored the growth and development of tomato plants leading to higher fruit yield. Weerakkody et al. [27] also obtained more tomato fruits, higher marketable yield and better fruit quality in protected tomato than in unprotected tomato.

In addition to tomato yields, the use of FRC and EFN also yielded better quality tomato fruit. Fruit harvested from FRC and EFN covered treatments were firmer with higher TSS, and TSS:TA but lower TA compared with control fruit. When tomato plants are grown under covers, their quality tends to be enhanced [23]. Findings of our study lend support to this argument. Fruit obtained from permanent covers tended to be of better quality than those from covers opened thrice a week. Fruit quality also tended to increase with decreasing cover pore diameter. Temperature and water are among the preharvest factors affecting quality of fruits. Weerakkody et al., and Borthwick [7,27] reported that temperature and water play an important role in quality development in fruits. Water and temperature have been reported to play a major role in photosynthesis, cell wall development, cell membrane integrity and ripening process of fruits $[6,25]$.
Modified internal temperature and high soil moisture under covers in the current study may have led to better photosynthetic activities and cell wall development leading to higher TSS, lower TA, higher sugar acid ratio and firm fruits under the covered treatments. Such fruit with higher TSS, lower TA, higher sugar acid ratio and firm are good indicators for fresh market consumption both in cooking and as salad.

Results of the present study demonstrate the potential of EFN and FRC as viable strategies for improving microclimate around tomato plants and improving tomato yields and quality. Besides, the use of these technologies also stands to reduction on the use of pesticides during tomato production due to the physical and visual barrier they create around the crop for insects. All these could lead to healthier fruits as well as contributing to environmental quality. While the findings of this study provide a good foundation to understanding the influence of EFN and FRC in microclimate modification and tomato performance, further testing of the technologies using a wider range of mesh sizes and colours, different tomato varieties and in different tomato growing agro ecological zones would be beneficial. A full economic analysis factoring in the cost of purchase, installation and management of EFN and FRC will also be of benefit to the growers.

\section{ACKNOWLEDGEMENTS}

This study was made possible by the generous support of the American people through the U.S. Agency for International Development (USAID) under Award No. EPP-A-00-09-00004. Additional financial support was provided by Michigan State University and the Centre de coopération internationale en recherche agronomique pour le developpement (Cirad). The contents are the responsibility of Horticulture Collaborative Research Support Program (HortCRSP) project BioNetAgro investigators and do not necessarily reflect the views of USAID or the U.S. Government. We acknowledge our project partners, the Egerton University, the Kenya Agricultural Research Institute (KARI) and the International Centre of Insect Physiology and Ecology (ICIPE) in Kenya; A to Z Textile Mills in Tanzania; University of Abomey Calavi, Institut National des Recherches Agricoles du Bénin (INRAB), and Association des Personnes Rénovatrices des Technologies Traditionnelles (APPRETECTRA) in Benin for their support.

\section{REFERENCES}

[1] Naika, S., de Jeude, J., de Goffau, M., Hilmi, M. and van Dam, B. (2005) Cultivation of tomato: Production, processing and marketing. Agromisa Foundation and CTA, Wageningen, Netherlands.

[2] Nkondjock, A., Ghadirian, P., Johnson, K. C. and Krewski, D. (2005) Dietary intake of lycopene is associated with reduced pancreatic cancer risk. Journal of Nutrition, 135, 592-597. 
[3] Gielen T., Ultzen, T., Bontems, S., Loots, W., van Schepen, A., Westerbroek, A., de Haan, T., Suzuki, M. and Kaneno, H. (1996) Coat protein-mediated protection to cucumber mosaic virus infections in cultivated tomato. Euphytica, 88, 139-149. http://dx.doi.org/10.1007/BF00032445

[4] Abate, T., van Huis, A. and Ampofo, J.K.O. (2000) Pest management. Review of Entomology, 45, 631-659. http://dx.doi.org/10.1146/annurev.ento.45.1.631

[5] Tumwine, J., Frinking, H.D. and Jedger, M.J. (2002) Integrated cultural control methods for tomato late Blight (Phytophthora infestans) in Uganda. Annals of Applied Biology, 14, 225-236.

http://dx.doi.org/10.1111/j.1744-7348.2002.tb00214.x

[6] Weerakkody, W.A.P. (1998) Evaluation and manipulation of the major environmental influences of tomato during the rainy season. Ph.D. Thesis, Postgraduate Institute of Agriculture, Paradeniya.

[7] Heinze, P.H. and Borthwick, H.A. (1952) The light controlled production of a pigment in the skins of tomato fruit. Program American Society of Plant Physiolgists, Ithaca, New York.

[8] Al-Helal, I.M. and Abdel-Ghany, A.M. (2010) Responses of plastic shading nets to global and diffuse PAR transfer: Optical properties and evaluation. NJAS-Wageningen Journal of Life Sciences, 57, 125-132. http://dx.doi.org/10.1016/j.njas.2010.02.002

[9] Martin, T., Assogba-komlan, F., Houndete, T., Jhougard, M. and Chandre, F. (2006) Efficacy of mosquito netting for sustainable small holder's cabbage production in Africa. Journal of Economic Entomology, 99, 450-454. http://dx.doi.org/10.1603/0022-0493-99.2.450

[10] Licciardi, S., Assogba-Komlan, F., Sidick, I., Chandre, F., Hougard, J. M. and Martin, T. (2007) A temporary tunnel screen as an eco-friendly method for small-scale farmers to protect cabbage crops in Benin. International Journal of Tropical Insect Science, 27, 152-158. http://dx.doi.org/10.1017/S1742758407883184

[11] Wells, O.S. and Loy, J.B. (1985) Intensive vegetable production with row covers. HortScience, 20, 822-826.

[12] Gogo, E. O., Saidi, M., Itulya, F. M., Martin, T. and Ngouajio, M. (2012) Microclimate modification using eco-friendly nets for high quality tomato transplant production by small-scale farmers in East Africa. HortTechnology, 22, 292-298.

[13] Muleke, E.M., Saidi, M., Itulya, F.M., Martin, T. and Ngouajio, M. (2013) The assessment of the use of ecofriendly nets to ensure sustainable cabbage seedling production in Africa. Agronomy, 3, 1-12. http://dx.doi.org/10.3390/agronomy3010001

[14] Soltani, N., Anderson, J. L. and Hamson, A. R. (1995) growth analysis of watermelon plants grown with mulches and row covers. Journal of the American Society for Horticultural Science, 120, 1001-1004.

[15] Kassilly, F. N. (2002) The fence as a moderator of wild- life menace in Kenya. African Journal of Ecology, 40, 407-409.

http://dx.doi.org/10.1046/j.1365-2028.2002.00401.x

[16] Tigchelaar, E.C. (1986) Tomato Breeding, In: Basset, M.J., Ed., Breeding Vegetable Crops. Intercept, Andover, pp. 135-171.

[17] Turhan, A. and Seniz, V. (2009) Estimation of certain chemical constituents of fruits of selected tomato genotypes grown in Turkey. African Journal of Agricultural Research, 4, 1086-1092.

[18] Gormley, T. R. and Maher, M. J. (1990) Tomato fruit quality-An Interdisciplinary. Professional Horticulture, 4, 7-12.

[19] Majumdar, A. (2010) Large-scale net-house for vegetable production: Pest management successes and challenges for a new technology. Alabama Cooperative Extension System, Auburn University, Alabama.

[20] Nair, A. and Ngouajio, M. (2010) Integrating row covers and soil amendments for organic cucumber production: Implications on crop growth, yield, and microclimate. HortScience, 45, 566-574.

[21] Harmanto, H., Tantau, J. and Salokhe, V.M. (2006) Microclimate and air exchange rates in greenhouses covered with different nets in the humid tropics. Biosystems Engineering, 94, 239-253. http://dx.doi.org/10.1016/j.biosystemseng.2006.02.016

[22] Antignus, Y., Lapidot, M., Hadar, D., Messika, M. and Cohen, C. (1998) Ultraviolet absorbing screens serve as optical barriers to protect greenhouse crops from virus diseases and insect pests. Journal of Economic Entomology, 9, 1140-1405.

[23] Waterer, D., Bantle, J. and Sander, T. (2003) Evaluation of row covers treatments for warm season crops. Saskatchewan Agriculture and Food. University of Saskatchewan, Saskatchewan, Canada.

[24] Moreno, D.A., Villora, G., Soriano, M.T., Castilla, N. and Romero, L. (2002) Floating row covers affect the molybdenum and nitrogen status of Chinese cabbage grown under field conditions. Functional Plant Biology, 29, 585-593. http://dx.doi.org/10.1071/PP01158

[25] Adams, S.R., Cockshull, K.E. and Cave, C.R.J. (2001) Effect of temperature on the growth and development of tomato fruits. Annals of Botany, 88, 869-877. http://dx.doi.org/10.1006/anbo.2001.1524

[26] Gerber, J.M., Splittstoesser, W.E. and Choi, G. (1989) A heat system for predicting optimum row tunnel removal time for bell peppers. Scientia Hort, 40, 99-104. http://dx.doi.org/10.1016/0304-4238(89)90091-5

[27] Weerakkody, W.A.P., Peiris, B.C.N. and Karunananda, P.H. (1999) Fruit formation, marketable yield and fruit quality of tomato varieties grown under protected culture in two agro-ecological zones during the rainy season. Journal of the National Science Foundation of Sri Lanka, 27, 177-186. 